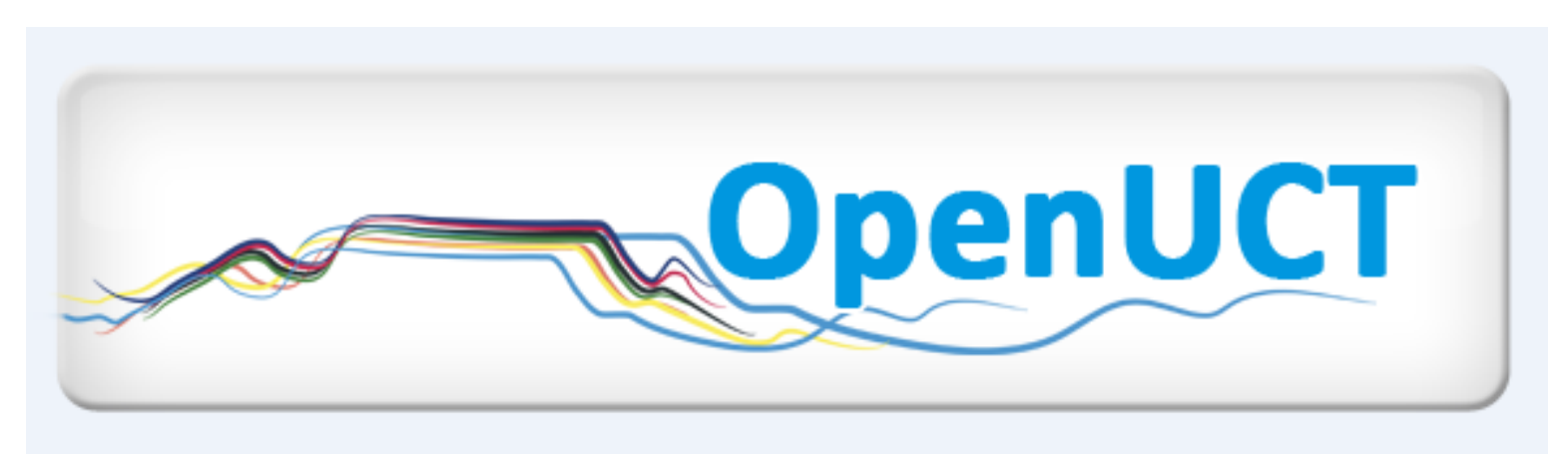

This is the post-print of Rollnick, M., Davidowitz, B.,Keane, M., Bapoo, A. \& Magadla, L. 2008. Students' learning-approach profiles in relation to their university experience and success. Teaching in Higher Education. 13(1): 29-42. DOI: 10.1080/13562510701792286.

It is made available according to the terms of agreement between the author and the journal, and in accordance with UCT's open access policy available:

http://www.openuct.uct.ac.za/sites/default/files/UCTOpenAccessPolicy.pdf, for the purposes of research, teaching and private study. 


\title{
Students' learning-approach profiles in relation to their university experience and success
}

\author{
Marissa Rollnick ${ }^{\mathrm{a}}$, Bette Davidowitz ${ }^{\mathrm{b}}$, Moyra Keane $^{\mathrm{a}}$, Abdool Bapoo $^{\mathrm{a}}$ and Lizo Magadla ${ }^{\mathrm{a}}$ \\ ${ }^{a}$ University of the Witwatersrand, South Africa; ${ }^{D}$ University of Cape Town, South Africa
}

\begin{abstract}
What is the connection between student success and their approaches to learning? Do learning approaches develop with university experience? We explored these questions by constructing profiles using a specially developed fixed response instrument and administering this to students at two similar South African universities. Groups consisted of access course applicants, access course students, and first and second year mainstream chemistry students. Successful senior students showed more sophisticated approaches to learning than other groups. Unsuccessful students fell into two different categories: those using a surface approach, and predominantly first generation tertiary students who used deep approaches. We discuss possible reasons for the latter group's lack of success. These findings raise questions for academic development practitioners advocating the use of deep approaches. The instrument was found to be useful for both diagnostic and pedagogic purposes.
\end{abstract}

Evidence of poor student performance in mathematics and science in South Africa abounds (CDE 2004). Tertiary institutions are plagued by poor throughput rates (Nair and Pillay 2004) and given the low output of the schools in science and technology, every student who fails or drops out is a significant loss.

Several studies in higher education suggest a connection between students' learning outcomes, their approaches to learning (e.g., Martin and Saljo 1976; Ramsden 2003) and their ability to reflect on their learning. Others have cited a close relationship between deep approaches, learning satisfaction and success in examinations (e.g., Ramsden 2003). Thus, understanding these characteristics can potentially play a crucial role in improving students' success rates. This paper outlines the development of an instrument that leads to categorising profiles of learning approaches. These profiles fall into four main groups and describe students at various stages through a science degree. The intention of this analysis was to examine study patterns and identify salient features linked to student success.

\section{Aim of the study}

The study develops and uses a fixed response learning-approaches questionnaire to develop profiles which identify connections between learning approaches, university experience and student success. We have chosen to measure student success in terms 
of their final course assessment, a composite assessment based on coursework and examinations.

In particular, we wished to find out:

- Whether a fixed response instrument could be constructed and used to develop profiles of students' intended learning approaches in relation to their success at university.

- Whether there is any connection between students' use of learning approaches and success at university.

- Whether there is any connection between university experience and students' adoption of learning approaches.

\section{Related literature}

Several models have been used to explain influences on student learning. Two of the most popular models look at learning styles (Kolb 1984) and learning approaches (Marton and Saljo 1976; Ramsden 2003). There are considerable differences between the models (Cuthbert 2005). Learning styles are regarded as fixed constructs that are characteristic of particular individuals, while learning approaches vary according to the demands of particular tasks. Different learning styles are not regarded as 'good' or 'bad', but merely different, while learning approaches, distinguished as 'deep' and 'surface', have connotations of quality associated with them.

Marton and Saljo (1976) distinguish between a deep and surface approach to learning. Ramsden $(2003,41)$ describes an approach as "a relation between the student and the learning he or she is doing". Students who learn by rote are often unable to construct a holistic understanding of what they are learning. This approach may allow them to pass examinations, but is about "quantity without quality" (Ramsden 2003). Deep learning approaches integrate facts into a holistic learning of concepts. Students with the ability to use deep approaches may use surface approaches when the task demands it, such as learning a large amount of material quickly for an examination, but do not find such tasks satisfying (Ramsden 2003). Thus, good performance in examinations may be a result of either surface or deep learning approaches, raising important concerns about the ability of examinations to identify effective learning (Hazel et al. 2002). While some progress is being made to change the nature of assessment (Ellery and Sutherland 2004), traditional examinations remain the major hurdle for success.

Other researchers in this area have identified a further factor, namely the use of strategic learning approaches (e.g., Entwistle and Ramsden 1983) where students focus on organised study, time management and monitoring their achievement. Such students may appear to use attributes of surface learning approaches to achieve a short-term objective. However, knowing when to be 'strategic' is often a necessary skill needed by students using deep approaches to learning.

Case and Marshall (2004) contend that there is a continuum between surface and deep approaches, which vary according to the intention of the student and the context of the learning task. They argue that any dichotomous view of surface and deep approaches, even one which allows a third classification, such as that of strategic learning or disintegrated learning orchestration (Hazel et al. 2002), ignore the complexity of the process of learning. A more useful construct for our purposes 
was that of metacognition, which was conceptualised by (Flavell 1981) as the ability to monitor one's learning. This is closely linked by Case and Gunstone (2002) to the idea of metacognitive development, described as a shift in students' approach to learning. Case and Marshall (2004) further note the close connection between approaches to learning and metacognitive development. More applicable to students at the tertiary level is the concept of epistemic cognition (Kitchener 1983), which is useful for solving ill-structured problems. The problem of how to approach learning may be studied using the reflective judgement model (RJM) of King and Kitchener (2004). In this model, seven stages are outlined, culminating in reflective thinking, regarded as important for the resolution of ill-structured problems. They assert that college students commonly display stage 4 (quasireflective reasoning). Unlike the learning-approaches perspective, the RJM suffers from many of the documented drawbacks associated with stage theories, but King and Kitchener defend this by offering what they call a complex stage theory as the explanation for transition between stages.

In an earlier study, Case et al. (2001) aimed to uncover chemical engineering students' experience of metacognitive development as they progressed through a course, emphasising reflection on learning. They identified three major aspects of metacognitive development.

1. Knowledge and awareness (conception of learning).

2. Control:

a. organising learning;

b. monitoring learning.

3. Purpose for learning beyond the subject.

These areas together form a framework for describing students' metacognitive development, and were particularly useful when linked to their intended learning approaches.

There have been critiques of the learning-approaches perspective, most recently by Haggis (2003), predominantly because such approaches are elitist. She attacks the learning-approaches perspective for assuming that students will find their way without the 'sign posting' that is often described as spoon-feeding. However, the close link between learning-approaches and metacognition suggests that interventions attempting to assist students to succeed often do attempt to provide scaffolding, or "signposts" to use Haggis' term (e.g., Case et al. 2001).

Haggis (2003) favours an 'academic literacies' approach which has close links with the question of epistemological access to university (Morrow 1994), an attribute that can only be acquired in practice through the joint efforts of the learner and the teacher, with the learner taking primary responsibility. It cannot be gained unless the learner is trying to learn and views the access as something worth gaining.

In response to Haggis' critique, Marshall and Case (2005), acknowledge conceptual slippage in the literature, and argue for a return to the original conception of the theory which describes learning approaches as context dependent and not characteristic of a particular learner. Seen in this light, the learningapproaches perspective is not necessarily in conflict with that of the academic literacies approach. Similar to Marshall and Case, we argue that the existence of 
approaches cannot be assumed a priori and that they need to be uncovered, not just by the use of surveys, but in the context of the social practice in which the students are participating (Lave and Wenger 1991). Hence, as argued below, we have opted for a more situated form of instrument than a survey.

Marshall and Case (2005) also argue that despite its information processing origins, recent incarnations of the learning-approaches theory have taken a more sociological turn, thereby taking into account many of the social issues raised by Haggis. We support Marshall and Case's contention that deep approaches to learning, far from being elitist, are desirable and attainable goals in higher education and are well complemented by perspectives such as that of academic literacy, particularly the links to metacognition as used in this paper. In fact, some of their research (Linder and Marshall 1997) carried out in a non-elitist university showed students ability to shift from an authoritarian view of the nature of science towards a more critical perspective.

One of the most popular ways of ascertaining learning approaches and perceptions of learning environments has been the use of surveys (e.g., McCune and Entwistle 2000). Surveys have come in for criticism, e.g., Haggis (2003) who claims they sample impressions rather than behaviour, particularly those using Likert scale responses, such as ASSIST (University of Edinburgh 2003). Instruments using Likert scales are popular in attitude research but have been criticised (Cohen et al. 2000). For example, Likert scales are often confusing to second language speakers, especially when one is invited to agree or disagree with negative statements; respondents tend to avoid choosing extremes on the scale, forcing the values to the centre; and most important of all, the technique makes no provision for respondents to provide their view in their own words. In view of the above, we opted instead to use the methodology of Bennett et al. (2001) of fixed response items developed from open-ended responses collected from the students themselves.

Our starting point was a questionnaire similar to those used in other studies (e.g., McCune and Entwistle 2000). However, our interest was in developing a more qualitative picture of student learning approaches. In each item, students are invited to reflect on an aspect of their learning and provide a response. The sample of item stems in Table 1 shows the close relationship between these and the metacognitive categories developed by Case et al. (2001). These categories provide a useful theoretical framework for the study.

Table 1. Sample stem items.

\begin{tabular}{|lc|}
\hline Statement & $\begin{array}{c}\text { Applicable category } \\
\text { (Case et al. 2001) }\end{array}$ \\
\hline $\begin{array}{l}\text { 1. I usually go over the work l've done to check the } \\
\text { reasoning and see that it makes sense. }\end{array}$ & Monitoring learning (2b) \\
$\begin{array}{l}\text { 2. It's important for me to be able to follow the argument, } \\
\text { or to see the reason behind things. }\end{array}$ & Knowledge and awareness (1) \\
$\begin{array}{l}\text { 3. Often I find myself wondering if my academic work } \\
\text { is really worthwhile. }\end{array}$ & $\begin{array}{c}\text { Purpose for learning beyond } \\
\text { the subject (3) }\end{array}$ \\
\hline
\end{tabular}




\section{Methods used}

The development of the instrument involved a multistage process where open-ended responses were sought for initial sets of statements. Here, students were required to select one option or to provide their own response if none of the options matched their point of view, thus integrating student voices into the instrument. A sample item is shown in Figure 1.

Rather than attempting an item by item analysis of responses, we used the semiquantitative analysis of Bennett et al. (2001) based on rating student responses. This yielded an overall profile of approaches to learning linked to student metacognition. The rating was carried out by the research team who rated each of the fixed responses on a scale of 1 to 7 , with 7 representing a deep learning approach and 1 , a surface approach.

The scale of 1 to 7 provides a wide enough range to allow differentiation between the students, but still allows sufficient criteria to make each level on the rating scale meaningful. Although the ratings were later manipulated as numerical values, the rating scale was not strictly linear, but more a descriptive category. However, the ratings were considered sufficiently evenly spaced to permit the calculation of means.

Consensus within the panel was reached by using the mode of individual ratings per fixed response when the difference between highest and lowest rating was 3 or less. Where the difference was greater, the rating was determined by discussion and consensus. The latter happened in only a few cases.

\section{Sample}

The four groups of students participating in this study were drawn from two similar institutions. Both are well-resourced urban universities with good reputations. The make-up of the student body at both institutions is largely similar in demography. The group from the first institution answered the questionnaire as part of a battery

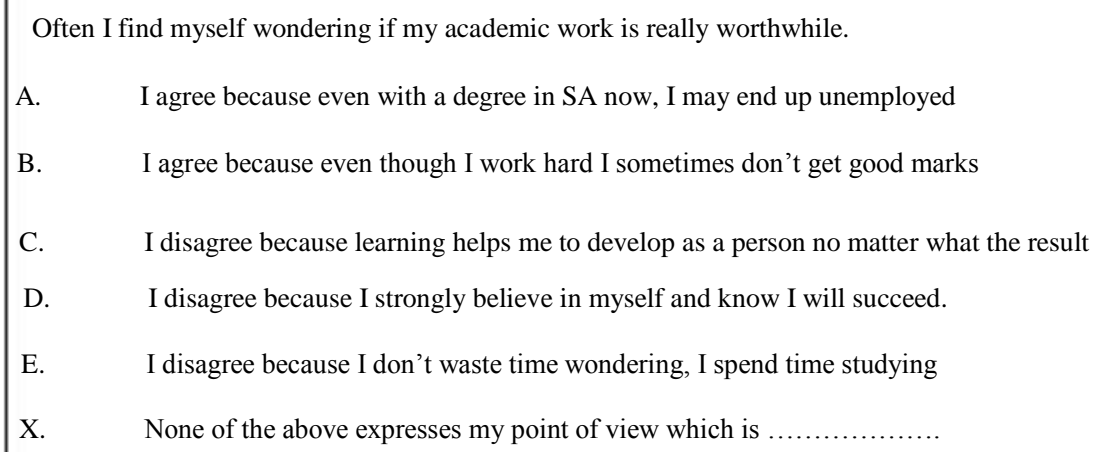

Figure 1. Sample item from questionnaire. Often I find myself wondering if my academic work is really worthwhile. (A) I agree because even with a degree in SA now, I may end up unemployed. (B) I agree because even though I work hard I sometimes don't get good marks. (C) I disagree because learning helps me to develop as a person no matter what the result. (D) I disagree because I strongly believe in myself and know I will succeed. (E) I disagree because I don't waste time wondering, I spend time studying. (X) None of the above expresses my point of view which is ... 
Table 2. Groups involved in the study.

No. of

\begin{tabular}{|c|c|c|c|}
\hline Group & Description & \multicolumn{2}{|c|}{ Institution respondents } \\
\hline Applicants & Successful applicants ${ }^{*}$ to an access course & 1 & 103 \\
\hline $\begin{array}{l}\text { First year } \\
\text { students }\end{array}$ & First year chemistry students & 2 & \\
\hline Access students & $\begin{array}{l}\text { Chemistry students in the second part of an access } \\
\text { course for under-prepared students* }\end{array}$ & 2 & 45 \\
\hline $\begin{array}{l}\text { Second year } \\
\text { students }\end{array}$ & Second year chemistry students & 2 & 107 \\
\hline
\end{tabular}

*Generally black students from disadvantaged backgrounds.

of selection tests. They were school leavers identified as possible entrants to an access programme, as their school leaving results did not qualify them for automatic admission to study science. The other three groups were current students from the second institution. Table 2 summarises the sample.

All students in the sample were later exposed to a similar regime of assessment, involving a 50Á60\% contribution from formal examinations, and the balance from tests, exercises and practical work.

\section{Data analysis}

For each student, an overall average rating was calculated from their responses to each item on the questionnaire (related to deep and surface approaches). The rating was then matched with the student's final results. The next step was the construction of profiles for the different groups of students in the study, viz. applicants, access, first year, and second year. The following procedure was followed for each group.

- Mean ratings of deep and surface approaches over the whole questionnaire were calculated for each student.

- Students were ranked in order of these ratings.

- Approximately the top $25 \%$ and bottom $25 \%$ of students were selected and labelled as favouring deep (D) and surface (S) approaches, respectively.

- The $D$ and $S$ categories were then ranked separately according to the students' final results.

- Approximately the top $40 \%$ and bottom $40 \%$ of both D and S categories were selected.

Thus four sub-groups were created, those favouring deep approaches to learning with high course marks ( $\mathrm{DH})$, students favouring surface approaches to learning with high course marks (SH), students with deep approaches and low course marks (DL), and students with surface approaches and low course marks (SL). In each case, these sub-groups comprised about $10 \%$ of the full group.

Tally charts were then used to produce a list of the responses to each item for the students within each sub-group. For example, the response pattern to a particular item for students in the DH sub-group might be ACAAADAA, but CBBBBDBB for students in the $S L$ sub-group, suggesting that response $A$ was most frequent for the $\mathrm{DH}$ sub-group, but that the SL sub-group was most frequently characterised by 
response $B$. The statements of the most frequently selected responses were then used to build up the 'profile' of students within each group. Only statements that occurred in more than $75 \%$ of the group were included in the profile.

The response pattern for each item within a sub-group (e.g., DH) was used to extract attributes. Where a statement emerged that was common to more than $50 \%$ of the entire group (e.g., the access group), it was used to describe the group as a whole and excluded from the sub-group profiles.

Statements that emerged during the construction of the profiles were classified independently by two of the researchers into the categories defined by Case et al. (2001). The process of assigning statements to categories proved relatively easy with agreement between the researchers in the majority of cases. Where differences occurred, these were resolved by discussion. Some statements were double coded into categories 1 and 3 , where they reflected changing as a person (category 1 ) and studying beyond the subject (category 3 ), both reflecting intrinsic values.

\section{Findings}

Profiles in terms of depth of approach and success

The profiles of the applicants, first year, access and second year students follow.

\section{Applicants}

The profiles according to the various categories (SL, SH, DH and DL) are shown in Table 3.

As expected, the views emerging in each of the categories are, in general, consistent with the descriptors, for example, both the DH and DL sub-groups include only views expressing a deep approach.

\section{First year students}

Table 4 shows the profiles of first year students. These students had been at university for one semester at the time of the data collection.

The students in this group entered university through normal selection, and thus were perceived as having a reasonable prospect for success. As expected, the profiles show clear definition of the SL and DH sub-groups. The DH sub-group shows

Table 3. Applicants' profiles (Case et al. (2001) categories in brackets).

\begin{tabular}{|c|c|}
\hline Low marks & High marks \\
\hline $\begin{array}{c}\text { Surface SL: Important to follow an argument as } \\
\text { approach there must be a reason behind it (1). } \\
\text { Entering HE to get a good job (3) }\end{array}$ & $\begin{array}{l}\mathrm{SH} \text { : Question what they read as they } \\
\text { may have misunderstood }(2 \mathrm{~b})\end{array}$ \\
\hline $\begin{array}{l}\text { Deep DL: Need to work independently (2a). } \\
\text { approach Prefer exams which offer opportunity to } \\
\text { apply knowledge (1) } \\
\text { Believe that it is more important to } \\
\text { understand than to memorise (1) }\end{array}$ & $\begin{array}{l}\mathrm{DH} \text { : Prefer to work steadily because } \\
\text { they like to learn not just to pass (3) }\end{array}$ \\
\hline
\end{tabular}


Table 4. First year students' profiles (Case et al. (2001) categories in brackets).

Surface SL: Prefer assessment to be based approach on their notes to make studying easier (2a). Often wonder if their academic work is worthwhile as hard work does not produce good marks (3)

Deep DL: Read and learn beyond what is approach required for passing because learning is about understanding and application (1)
SH: Important to follow an argument as there must be a reason behind it (1). Read beyond requirements to pass because reading improves their exam marks (2a). Do not read ahead because to understand they have to be taught material first $(2 b)$

$\mathrm{DH}$ : Find academic work worthwhile as it helps them to develop as people. $(1 / 3)$ Learn beyond requirements for tests and exams (3). Prefer to work steadily because they like to learn not just to pass (3)

an orientation towards the long-term benefits of education (Case et al. 2001; category 3 ) and may show a more idealistic and less strategic approach. In this case, the idealism appears to have paid off and their performance shows that they have been successful. The SL sub-group appears distressed at their poor performance, preferring a narrower approach to testing. The SH sub-group on the other hand, recognise the need for understanding, but are strategic in adopting surface approaches to learning and assessment.

\section{Access students}

Table 5 shows the profiles obtained for the access students:

The profiles in Table 5 should be viewed bearing in mind that students in this group entered the university with lower than the minimum entry requirements, and can be considered to be at risk. Therefore, it comes as no surprise to find little in the DH category that allows a clear characterisation of these students, but a more definitive profile emerges for the SL and DL students.

The SL sub-group shows a 'reproducing orientation' profile marked by poor time management and a preference for being fed information. The profile of the DL subgroup is interesting with students presenting differing though not inconsistent views on learning. Apart from seeing learning as acquiring facts, these students present a profile associated with a deep approach. The use of this approach is clearly not successful. Many of these students have not acquired the necessary strategic skills necessary for survival at university.

\section{Second year students}

Table 6 shows the profiles of the second year students.

The views of the second year students are similar to their first year counterparts, but show more sophistication in the DH sub-group. There are also similarities between the DL and DH sub-groups, but the DH sub-group places greater emphasis on intrinsic learning (Case et al.'s (2001) category 3). The SL sub-group is also 
Table 5. Access students' profiles (Case et al. (2001) categories in brackets).

\begin{tabular}{|c|c|c|}
\hline & Low marks & High marks \\
\hline $\begin{array}{l}\text { Surface } \\
\text { approa }\end{array}$ & $\begin{array}{l}\text { SL: Leave studying till the last } \\
\text { minute, because they forget } \\
\text { everything if they start too early } \\
\text { (2a). Do not read ahead because } \\
\text { to understand they have to be taught } \\
\text { material first (2b) }\end{array}$ & $\begin{array}{l}\mathrm{SH} \text { : Believe that 'learning' means } \\
\text { building up knowledge by acquiring } \\
\text { facts and information (1). Like to } \\
\text { make studying easier by being told } \\
\text { exactly what to write in their notes } \\
\text { (1), basing assessment on their notes (2a) }\end{array}$ \\
\hline $\begin{array}{l}\text { Deep } \\
\text { approach }\end{array}$ & $\begin{array}{l}\text { DL: Believe that learning means } \\
\text { knowledge by acquiring } \\
\text { facts and information ( } 1) \text {; is about } \\
\text { broadening the mind not just learning } \\
\text { facts for passing ( } 1 / 3) \text {; is also about } \\
\text { understanding and application (1). } \\
\text { Find academic work worthwhile as it } \\
\text { helps them to develop as people (1/3). } \\
\text { Like challenging books that provide } \\
\text { deeper explanations and so learn } \\
\text { beyond what is required for passing (1) }\end{array}$ & $\begin{array}{l}\mathrm{DH} \text { : Usually go over their work to check building up } \\
\text { for mistakes }(2 \mathrm{~b})\end{array}$ \\
\hline
\end{tabular}

clearly defined by surface approaches and is similar to the first year SL sub-group in that they are also despondent about working to no effect. The SH sub-group is particularly interesting in that they appear to use surface approaches successfully. However, closer examination of the SH profile shows a mixture of approaches possibly indicating a strategic approach.

\section{Commonalities in profiles}

Common attributes were those opinions held by more than $50 \%$ of the respondents in each group, shown in Table 7.

A striking feature of Table 7 is the predominance of ideas on understanding, common to all groups particularly in the 'knowledge and awareness' and 'monitoring learning' categories. All four groups are keenly aware of the importance of understanding material. The views held by the majority of students already in the university system are more similar to each other than those held by the applicants. The latter's views are a mix of deep and surface approaches, showing a search for understanding tempered by pragmatism. All but one of the applicants' attributes reflects deep approaches. The common attributes of the second year students are a subset of those found for both the access students and the first year students with one notable exception; that of reading beyond what is required. These students can be regarded as successful in that they have reached the second year in a three-year degree. Chemistry is a major of choice, thus they express an intrinsic interest in the discipline. The emergence of this attribute is also a sign of maturity in the learning approaches of students as the demands made on them in the course. The first year students display similar views to the access students with one fundamental difference*the access group wonder if academic work is worthwhile, a statement that amounts to a cry of desperation. It appears that the access students are 
Table 6. Second year students' profiles (Case et al. categories in brackets)

\begin{tabular}{|c|c|c|}
\hline & Low marks & High marks \\
\hline $\begin{array}{r}\text { Surface } \\
\text { approach } \\
\\
\mathrm{n} \\
\mathrm{n}\end{array}$ & $\begin{array}{l}\text { SL: Try to impress the marker } \\
\text { to get good marks when writing } \\
\text { assignments }(2 b) \text {. Often wonder if } \\
\text { academic work is worthwhile as } \\
\text { hard work does not produce good } \\
\text { marks (3). Usually go over their work } \\
\text { to check for mistakes (2b) }\end{array}$ & $\begin{array}{l}\text { SH: Like to be told exactly what } \\
\text { to write in their notes to make } \\
\text { work easy (1). Try to link ideas } \\
\text { between topics because it gives } \\
\text { them a better idea of how things } \\
\text { work (1). Learn material beyond what } \\
\text { is required for passing to enhance } \\
\text { understanding but books that provide } \\
\text { extra challenge are irrelevant (1) }\end{array}$ \\
\hline \multirow[t]{2}{*}{$\begin{array}{l}\text { Deep } \\
\text { approach }\end{array}$} & $\begin{array}{l}\text { DL: See assignments as a means of } \\
\text { checking understanding (1) }\end{array}$ & $\begin{array}{l}\mathrm{DH} \text { : Prefer exams and assignments that } \\
\text { are challenging and elicit opinion and } \\
\text { understanding (1). Entering HE to be } \\
\text { able to study subjects in depth and take } \\
\text { interesting courses. Find academic work } \\
\text { worthwhile as it helps them to develop as } \\
\text { people }(1 / 3) \text {. Prefer to work steadily } \\
\text { because they like to learn not just to } \\
\text { pass (3) }\end{array}$ \\
\hline & $\begin{array}{l}\text { Believe that learning is about } \\
\text { broadening the mind not just learning } \\
\text { facts needed to pass, hence will read } \\
\text { beyond that is required to pass }(1 / 3)\end{array}$ & \\
\hline
\end{tabular}

attempting to use understanding-based approaches to learning without much success.

\section{Discussion}

In developing profiles of students' learning approaches, we were aware that these approaches could vary according to context. However, in this study we were seeking commonalities within a group in a similar context to allow diagnosis of student learning difficulties at an early stage.

This argument goes some way towards addressing our first research question, on the use of the instrument. The instrument is able to generate identifiable profiles but can be challenged on two issues. First, the use of final results as an indicator of understanding can be questioned. Green and Rollnick (2007) demonstrated that the most common level of testing in university chemistry examinations is Bloom's level 2 (understanding), exposing the limitation of examinations in testing higher cognitive levels. Although the final marks used in our study contained other components, such as practical reports, the major part of formal assessment in undergraduate courses does not give students the opportunity to demonstrate their use of deep approaches. Minbashiam et al. (2004) confirm that the nature of time-tested examinations severely limits the use of deep approaches. However, student success continues to be measured by their ability to pass examinations, and hence any profiles constructed need to be used to assist students to achieve this objective. 
Table 7. Common attributes emerging from the different groups

\begin{tabular}{|c|c|c|c|c|}
\hline & Applicants & First year & Access & Second year \\
\hline \multirow[t]{4}{*}{$\begin{array}{l}\text { 1. Knowledge and } \\
\text { Awareness }\end{array}$} & $\begin{array}{l}\text { Id Question issues to improve } \\
\text { understanding. }\end{array}$ & $\begin{array}{l}\text { Follow an argument for } \\
\text { understanding. }\end{array}$ & & \\
\hline & $\begin{array}{l}\text { Believe it is more important to } \\
\text { understand than to memorise. } \\
\text { Read beyond what is required } \\
\text { because learning is about } \\
\text { understanding and application. }\end{array}$ & & $\begin{array}{l}\text { Believe it is more important to } \\
\text { understand than to memorise. } \\
\text { Learning implies being able to } \\
\text { use knowledge. }\end{array}$ & $\begin{array}{l}\text { Read beyond what is } \\
\text { required because } \\
\text { learning is about } \\
\text { understanding and } \\
\text { application. }\end{array}$ \\
\hline & Prefer challenging exams. & $\begin{array}{l}\text { Like to do precisely what the } \\
\text { lecturer wants. }\end{array}$ & & \\
\hline & $\begin{array}{l}\text { 'Learning' means building up } \\
\text { knowledge by acquiring facts } \\
\text { and information. }\end{array}$ & $\begin{array}{l}\text { Like materials that can be easily } \\
\text { learned and remembered. }\end{array}$ & & \\
\hline $\begin{array}{l}\text { 2a. Organising } \\
\text { learning }\end{array}$ & $\begin{array}{l}\text { Believe in planning their work in } \\
\text { advance because it helps them to } \\
\text { manage their time and work hard. }\end{array}$ & & & \\
\hline \multirow[t]{2}{*}{$\begin{array}{l}\text { 2b. Monitoring } \\
\text { learning }\end{array}$} & $\begin{array}{l}\text { Stop periodically to ensure what } \\
\text { they are learning makes sense. } \\
\text { See assignments as a means of } \\
\text { checking understanding. }\end{array}$ & & & \\
\hline & $\begin{array}{l}\text { Do not like teachers who tell them } \\
\text { exactly what to write as they want } \\
\text { to understand for themselves. }\end{array}$ & $\begin{array}{l}\text { Question issues to } \\
\text { improve understanding. }\end{array}$ & & \\
\hline \multirow[t]{2}{*}{$\begin{array}{l}\text { 3. Purpose for } \\
\text { learning }\end{array}$} & $\begin{array}{l}\text { To study subjects in depth and } \\
\text { take interesting courses. }\end{array}$ & Enter HE to get a good job. & & \\
\hline & & & $\begin{array}{l}\text { Wonder if academic work is } \\
\text { worthwhile as hard work does } \\
\text { not produce good marks }\end{array}$ & \\
\hline
\end{tabular}


The second issue relates to the apparent circularity of the process of determining the profiles. By sorting the students according to their average ratings on the questionnaire as a whole, it would be expected that the DL and DH sub-groups would contain only statements expressing a deep approach to learning. As can be seen from the profiles, this was not universally the case. Further, by including only statements that occurred in $75 \%$ of the sub-group, the profile presented only the strongest emerging trends, which was the main purpose of the instrument.

In response to the second question concerning the profiles of students' use of learning approaches and success at university, clear differences emerged between the $\mathrm{SL}$ and the DH sub-groups despite the differences in profiles among the groups in the study. The DH sub-groups reflected only deep approaches, with the possible exception of the access students, who it has been noted did not perform well. This suggests that in the absence of good performance, the attributes associated with a deep approach to learning do not emerge in the profile. The DH category also grows in sophistication and richness as one examines students higher up in the system, such as the second year students. Both these points appear to support the existence of a connection between deep approaches and academic success, particularly at the higher level. Equally, the SL sub-groups also showed a clear profile fitting the definition of Ramsden (2003) of surface approaches.

Research question three interrogated the variation of profiles in relation to university experience. The applicants who were answering the questionnaire as part of a selection test, professed primarily deep approaches to learning, while the views emerging from the current students were influenced by their actual experiences at university. However, as noted above, some developmental trends are observed as the students' progress through the system. An examination of the responses in Table 6 shows sophistication in learning approaches in the second year students, particularly in the $\mathrm{DH}$ and $\mathrm{DL}$ sub-groups.

Comparing the second year profiles with those of the access students, a picture emerges of second year students who have become full participants in the social practice of being a student in contrast with access students who are still legitimate peripheral participants (Lave and Wenger 1991). In a case study of second year students from the same population, Davidowitz and Rollnick (2003) found a strong link between metacognition and a deep approach to learning. It may be that by year 2 , students who have managed to remain in the system have moved some way towards gaining epistemological access to the university or, in Haggis's (2003) terms, they have acquired some of the necessary academic literacies that allow them access to the subject. She makes the point that such knowledge is regarded as tacit and frequently not shared with novice students.

This point is further strengthened when examining the profile of the access students, particularly the richness of the DL category. There is documented evidence of staff working with access students, encouraging them to use deep approaches (Grayson 1996). As first generation students, they enter the university with little tacit knowledge of the tertiary environment, and hence do not readily gain epistemological access (Morrow 1994). Practitioners in the field of academic development may be overcompensating for students' previous experience of transmission mode instruction in that they do not pass on to students the imperative to use surface approaches strategically when demanded. 
This apparent contradiction between what academics perceive to be 'good learning practice' and actual practice that generates success for students may be explained by the argument of Haggis (2003) that the key to success is the acquisition of academic literacies, together with an awareness that the discourse to be acquired may be different to their local discourse but applicable in the field of study. For example, Boughey (2002) argued that English language courses that aim to teach 'correct English' rather than appropriate discourse, do not provide epistemological access, and hence do not give the students the tools for success.

\section{Conclusions}

The usefulness of the profiles developed lies in identifying obstacles to study. While it would be too time-consuming to administer the questionnaire and construct profiles for every cohort of students, it would be possible to adapt the attributes found as a simple checklist that could be administered to obtain a snapshot of the student cohort in terms of deep and surface approaches to learning. The instructor could use the responses to assist students to adjust their learning approaches. Our study found that the higher quality learning experiences were associated with courses where approaches to teaching were coherently related to students' perceptions of the teaching and learning context. The use of metacognition and students' understanding of learning approaches may thus provide the insight that clears the way to successful study at university. For those planning to use these learning profiles, cognisance should be taken of the context of the students' study environment as well as their prior experiences and identity.

\section{Acknowledgements}

We gratefully acknowledge grants from the National Research Foundation and the University of Cape Town (UCT) Research Committee. We would also like to thank Fred Lubben (University of York), Jenni Case (UCT) and Peter Hewson (University of Wisconsin) for helpful comments on this paper.

\section{References}

Bennett, J., M. Rollnick, G. Green, and M. White. 2001. The development and use of an instrument to assess students' attitude to the study of chemistry. International Journal of Science Education 23, no. 8: 833Á45.

Boughey, C. 2002. Naming' students' problems: an analysis of language-related discourses at a South African university. Teaching in Higher Education 7, no. 3: 295Á307.

Case, J., and R. Gunstone. 2002. Metacognitive development as a shift in approach to learning: an in-depth study. Studies in Higher Education 27, no. 4: 459Á70.

Case, J., and D. Marshall. 2004. Between deep and surface: procedural approaches to learning in engineering education contexts. Studies in Higher Education 29, no. 5: 605Á15.

Case, J., R. Gunstone, and A. Lewis. 2001. Students' metacognitive development in an innovative second year chemical engineering course. Research in Science Education 31: 313Á 35.

CDE. 2004. From laggard to world class: reforming maths and science in South Africa's schools. Research Report No. 13. Johannesburg, Centre for Development and Enterprise.

Cohen, L., L. Manion, and K. Morrison. 2000. Research methods in education, 5th edn. London: RoutledgeFalmer. 
Cuthbert, P.F. 2005. The student learning process: learning styles or learning approaches? Teaching in Higher Education 10, no. 2: 235 Á49.

Davidowitz, B., and M. Rollnick. 2003. Enabling metacognition in the laboratory: a case study of four second year university chemistry students. Research in Science Education 33, no. 1: 43Á69.

Ellery, K., and L. Sutherland. 2004. Involving students in the assessment process. Perspectives in Education 22, no. 1: $99 A ́ 110$.

Entwistle, N.J., and P. Ramsden. 1983. Understanding student learning. London: Croom Helm.

Flavell, J.H. 1981. Cognitive monitoring. In Children's oral communication skills, ed. P. Dickson. New York: Academic Press.

Grayson, D. 1996. A holistic approach to preparing disadvantaged students to succeed in tertiary science studies. Part I. Design of the Science Foundation Programme (SFP). International Journal of Science Education 18, no. 8: 993Á1013.

Green, G., and M. Rollnick. 2007. Let's stop complaining about low cognitive levels of testing in time-limited examinations: the case for fair testing practices. South African Journal of Higher Education 21, no. 2: 255Á66.

Haggis, T. 2003. Constructing images of ourselves? A critical investigation into 'approaches to learning' research in higher education. British Educational Research Journal 29, no. 1: 89Á 104.

Hazel, E., M. Prosser, and K. Trigwell. 2002. Variation in learning orchestration in University biology courses. International Journal of Science Education 24, no. 7: 737Á51.

King, P.M., and K.S. Kitchener. 2004. Reflective judgment: theory and research on the development of epistemic assumptions through adulthood. Educational Psychologist 39, no. 1: 5Á18.

Kitchener, K.S. 1983. Cognition, metacognition and epistemic cognition: a three-level model of cognitive processing. Human Development 26: 222 Á32.

Kolb, D.A. 1984. Experiential learning: experience as the source of learning and development. Upper Saddle River, NJ: Prentice-Hall.

Lave, J., and E. Wenger. 1991. Situated learning: legitimate peripheral participation. Cambridge: Cambridge University Press.

Linder, C., and D. Marshall. 1997. Introducing and evaluating metacognitive strategies in large-class introductory physics teaching. In Improving student learning: improving students as learners, ed. C. Rust. Oxford: Oxford Centre for Staff and Learning Development.

Marshall, D., and J. Case. 2005. Approaches to learning' research in higher education: a response to Haggis. British Educational Research Journal 31, no. 2: 257 Á67.

Marton, F., and R. Saljo 1976. Qualitative differences in learning: I-outcome and process." .". British Journal of Educational Psychology 46: 4Á11.

McCune, V., and N. Entwistle . 2000. The deep approach to learning: analytic abstraction and idiosyncratic development. Paper presented at the Innovations in Higher Education Conference, 30 August to 2 September 2000, Helsinki, Finland. Available online at: http://www.ed.ac.uk/etl/docs/mccune2000.pdf (accessed 12 June 2006).

Minbashiam, A., G. Huon, and K. Bird. 2004. Approaches to studying and academic performance in short-essay exams. Higher Education 47: $161 \mathrm{~A} 76$.

Morrow, W. 1994. Entitlement and achievement in education. Studies in Philosophy and Education 13: 33Á47.

Nair, A.P., and J. Pillay. 2004. Exploring the validity of the continuous assessment strategy in higher education institutions. South African Journal of Higher Education 18, no. 2: $302 A 12$.

Ramsden, P. 2003. Learning to teach in higher education, 2nd edn. London and New York: Routledge Farmer.

University of Edinburgh. 2003. Approaches and study skills inventories for students (ASSIST). Available online at: http://www.ed.ac.uk/etl/questionnaires/ASSIST.pdf (accessed 12 June 2006). 